\title{
Transcription Factor Sp3
}

National Cancer Institute

\section{Source}

National Cancer Institute. Transcription Factor Sp3. NCI Thesaurus. Code C98045.

Transcription factor Sp3 (781 aa, $\sim 82 \mathrm{kDa}$ ) is encoded by the human SP3 gene. This protein plays a role in both DNA binding and the regulation of gene transcription. 